\title{
Western Mediterranean coastal waters-Monitoring PCBs and pesticides accumulation in Mytilus galloprovincialis by active mussel watching: the Mytilos project
}

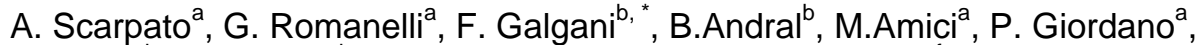 \\ M. Calvo ${ }^{d}$, J. Caixach ${ }^{d}$, J.A. Campilloc ${ }^{c}$, J. Benedico ${ }^{c}$, A.Cento $^{\dagger}$, S. BenBrahim ${ }^{g}$, \\ M. Elbour ${ }^{\mathrm{h}}$, S. Deudero ${ }^{\mathrm{e}}$, M.Boulahdid' \& F.Giovanardi ${ }^{\mathrm{a}}$
}

\footnotetext{
${ }^{a}$ Istituto Centrale per la Ricerca Scientifica e Tecnologica Applicata al Mare (ICRAM), Via di Casalotti 300, 00166 Roma, Italy.

${ }^{b}$ IFREMER. Laboratoire Environment Ressource Provence Azur Corse, BP 330, 83507 La Seyne sur Mer Cedex, France.

${ }^{c}$ Instituto Español de Oceanografía, Centro Oceanográfico de Murcia, C/Varadero 1, 30740, San Pedro del Pinatar, Spain.

${ }^{d}$ Chemical and Environmental Research Institute of Barcelona of Spanish National Research Council (IIQABCSIC), Jordi Girona, 18-26, 08034 Barcelona, Spain.

e Laboratorio de Biología Marina and GOI-IMEDEA (CSIC-UIB), Guillén Colom, Campus Universitari, Ctra. de Valdemosa, km 7.5, 07122 Palma de Mallorca, Spain.

${ }^{f}$ Parco Scientifico e Tecnologico della Sicilia, Z.I. Blocco Palma, 1 s.s. G. Agnelli, 95030 Catania, Sicilia, Italy.

${ }^{9}$ Institut National de Recherche Halieutique (INRH), 2, rue de Tiznit, Casablanca 04, Morocco.

${ }^{h}$ Institut National des Sciences et Technologies de la Mer (INSTM), Port de pêche la Goulette, 2060, Tunis, Tunisie.

'ISMAL,bois des cars, BP 19, 16320, Alger, Algeria
}

*: Corresponding author : F. Galgani, email address : Francois.Galgani@ifremer.fr

\begin{abstract}
:
In order to evaluate the contamination levels in the Western Mediterranean basin, the active mussel watch methodology has been applied. This methodology consists of mussel transplantation (Mytilus galloprovincialis) from non impacted areas to selected coastal areas, characterised by potential impact from the continent due to contaminating sources. The areas of interest were selected along the entire coastal development of the Western Mediterranean sea, 122 sites in total. The time of mussel caging exposure was 12 weeks. The project was co-financed in the frame of the Interreg IIIB Meddoc Programme, aimed at determining the overall chemical quality of the Mediterranean sea, consistent with the Water Framework Directive 2000/60. Several partners representative of the coastal Mediterranean Countries were involved in the Project, with the purpose of building up a common surveillance network, adopting shared methodologies. In this paper we present the results of three yearly monitoring campaigns $(2004,2005,2006)$ carried out along the coasts of Italy, France, Spain, Morocco, Algeria and Tunisia, including the coastal environment of Baleares, Sicily, Sardinia and Corsica. The contamination levels of Pesticides (DDT and its metabolites, Hexachlorocyclohexane isomers $\alpha$ and $\gamma$ ) and Polychlorinated biphenyls, are reported and discussed. Statistical elaborations performed on the original data set were mainly aimed at validating the raw sample distributions, by means of the Johnson method. Both DD and PCB species frequency distributions have been approximated to appropriate theoretical distributions, belonging to the Log-normal and Bounded families. By integrating the related Probability Density Functions (p.d.f.), different accumulation values for DDT, DDD and DDE and PCB species have been estimated, corresponding to fixed percentage points of the area under the respective curves. By choosing appropriate probability level boundaries (33rd and 66th percentile), different regional zones have been ranked in terms of low, medium and high accumulation for Pesticides and PCBs.
\end{abstract}

Keywords: mussel caging, PCBs, Pesticides, bioaccumulation, Mytilus galloprovincialis, Mediterranean sea 


\section{Introduction}

As filter feeder organisms, mussels are able to accumulate chemical contaminants, with an accumulation degree that can result proportional to the relative occurrence of these substances in the surrounding environment. This paper presents and discusses the results of a surveillance programme based on the use of the mussel caging technique.

Western Mediterranean basin is heavily affected by polluting loads, coming from urban and industrial waste water discharges. Further pollution and organic contamination arises from diffuse sources through agricultural and urban runoff and from river discharge contributions (Tolosa et al., 1997; Carvalho and Civili, 2000; Gòmez-Gutiérrez et al., 2006).

Among contaminant substances, organochlorinated compounds, namely PCBs and DDs, are ubiquitous contaminants whose occurrence in the environment represents special concern due to their physical-chemical properties: high fat solubility, resistance to degradation, scarce water solubility (Geyer et al., 1984). In marine environment these compounds are especially subject to accumulation in sediments and biota, that is to say the matrices most often analysed for pollution monitoring purposes (Tolosa et al., 1995).

PCBs is a large class of substances (209 congeners) that assume particular physical and chemical properties depending on the chlorine substitution on the biphenyl rings (see e.g. Erickson, 1997). The potential toxic effects of a PCB congener are also structure-dependent. Several studies suggest that the non ortho-chlorine substituted PCBs, are able to adopt a planar conformation that increases their toxicity (Storelli et al., 2004). In general, PCB compounds exhibit a broad range of toxicological responses, including immunotoxicity, reproductive deficits, teratogenicity, endocrine toxicity and carcinogenity/tumor promotion (Ahlborg et al., 1994; Canesi et al., 2002).

Organochlorinated pesticides, such as DDT and its metabolites (DDs) and $\mathrm{HCHs}$ ( $\mathrm{HCH}$ isomers), are also contaminants of high concern, because of their toxicity and persistence in the environment.

Despite the ban of these classes of compounds in the majority of the industrialized countries of the northern hemisphere (Kannan et al., 1995), they are usually found in the marine environment at detectable concentrations.

Monitoring of these contaminants in the Mediterranean began in the mid of the seventies, after the Barcelona Convention approval, that promoted the Mediterranean Action Plan (MAP) and its environmental assessment programmes (Programme for Pollution Monitoring and Research in the Mediterranean Sea - MED POL) (UNEP/FAO, 1990; UNEP/WHO, 1999).

Following these monitoring programmes, several works have been published, concerning the environmental contamination levels along the Mediterranean coasts at a national scale. Different aspects of PCB and Pesticides contamination, including the related partitioning in different marine matrices (sediments, biota and water column), have been highlighted (Elder and Villeneuve, 1977; Villeneuve et al., 1999; Marchand et al., 1974; Amico et al., 1982; Puccetti and Leoni, 1980; Fernandez et al. 1999; Bazzanti et al., 1997; De Simone, 1994). However, despite recent improvements in the analytical methods, monitoring data provided by different laboratories and obtained with not standardised and shared methodologies, do not allow a sure and comprehensive evaluation of the contamination levels to be reached, at a basin scale. On the other hand, one of the goals of the MED POL programmes, was surely aimed at developing and enhancing the capabilities of the laboratories involved in the monitoring activities: training courses, testing for new analytical methodologies, availability and use of Reference Material and Quality Assurance programmes have been promoted and implemented throughout different phases of the MED POL (Carvalho and Civili, 2001).

Mytilos project (see http://mytilos.tvt.fr/), started in January 2004, in the frame of the INTERREG III B MEDOCC programme, for a duration of three years. EU Member Countries involved in this project were France, Italy, and Spain. The South coast of the Mediterranean was instead represented by Morocco, Algeria and Tunisia. Scope of the programme was to reach a valid and consistent level of knowledge referred to the chemical contamination status along the Western Mediterranean coasts by setting up a network of partners that adopted the same evaluation and 
measurement procedures, that is to say the "active mussel watch" methodology (Andral et al., 2004).

Mussel watching procedures were already utilised and tested along the French coasts (RINBIO, 1999), as a tool for contamination level measurements by means of a living organism, $M$. galloprovincialis, chosen as a "bio-integrator".

The use of indigenous populations of wild or cultivated mussels to assess levels and trends in the chemical contamination of coastal waters was firstly tested and applied in the seventies by Goldberg (1975). More recently, "active bio-monitoring strategy" has been adopted, based on mussels transplantation from unpolluted or not impacted areas to selected coastal zones, characterised by potential impact from the continent due to contaminating sources (Kock and Kramer, 1994; Gunther et al., 1999; Romeo et al., 2003). The advantages of adopting this technique are mainly to be referred to 1 ) the often scarce natural mussel stocks in several coastal areas, 2) the control of factors like: exposure times, depth of caging, age, size, stage of sexual maturity (immersion should preferably take place during the period of sexual dormancy), and other physiological factors that can interfere and affect the accumulation mechanisms of contaminating substances.

The Mytilos project provides an important basis of experience for future large scale monitoring programmes. Moreover, the richness of the data produced and currently available, represents a valid tool for interpreting the above mentioned mechanisms characterising bio-accumulation. At this concern, we report the results of statistical elaboration and data processing, that allows to understand statistical behaviour of each DD and PCB species in terms of probability distributions. Based on the theoretical range of variation of the accumulation data, it is now possible to propose a preliminary classification criterion in order to characterise and make comparisons among coastal areas and consequently, to fix boundaries beyond which critical conditions can be identified.

\section{Materials and methods}

\subsection{Mussel Caging}

Mussels to be transplanted came from an aquaculture farm located in an unpolluted area of the French coast in Languedoc-Roussillon. The batch was made up with adult mussels 18-24 months old, of standardized shell size $(50 \pm 5 \mathrm{~mm})$. Before transplant, mussels (an amount of approximately $3 \mathrm{~kg}$ ), were collected and stored in polyethylene bags, then re-immersed in situ for ten days to permit them to re-cluster; this practice aims to reduce the mortality risk during transplantation.

Mussel cages were then transported from the farm to the oceanographic vessel by means of a refrigerated container and then maintained on board in a tub. Finally, the cages were immersed and anchored at the bottom with a ballast of $30 \mathrm{~kg}$.

Station sites were located in the coastal belt, between 20 and 40 meters bathymetric lines; mussel bags were suspended by means of a buoy at 6 - 8 meters depth from the sea surface.

\subsection{Sample treatment}

During recovery, mortality of the mussels and other biometric parameters were recorded, in particular: length, width, and height of the shells. Tissues of an adequate number of mussels were separated from the shells, divided in shares, weighed and then frozen at $-20^{\circ} \mathrm{C}$. Before the chemical analysis, mussel tissues were dried and homogenized.

In order to determine the Condition Index (C.I.), 15 mussels were chosen and the height of each shell was measured. Shells were cleaned up by any remaining flesh and limestone, then dried at $60^{\circ} \mathrm{C}$ for 48 hours, and weighed. The ratio between the dry weight of the flesh and the dried weight of the shells represents the Condition Index. 


\subsection{Chemical analysis}

Each Partner analysed samples collected in its own country, according to their own methodologies. At the same time, IFREMER proceeded to analyse each contaminant on the whole samples, in such a way that two series of analytical results for each sample, are now available.

PCB congeners analysed were the following: 28, 31, 52, 101, 105, 118, 138, 153, 156, 180.

Pesticides analysed were: pp'-DDT, pp'-DDE, pp'-DDD, $\alpha-\mathrm{HCH}, \mathrm{\gamma}-\mathrm{HCH}$.

Analytical procedure was the following: $5 \mathrm{~g}$ of freeze-dried sample were extracted by PLE (Pressurized Liquid Extraction) with a mixture of n-hexane/acetone (50/50). Measured volume of a solution containing known quantity of PCB 205 and 207 was added to the organic extracts as surrogates, for recovery estimates. Prior to the clean up, the extract was concentrated under Nitrogen stream by automated system TurboVap LV; then $1 \mathrm{ml}$ of a solution containg known amount of PCB 209 as internal standard was added to the extract.

The clean up was made by adding concentrated sulphuric acid to the extract.

Analyses were performed by capillary gas chromatography coupled with Electron Capture Detector, equipped with two column of different polarities. For each chlorinated organic contaminant, quantitation limit of the method was $1 \mu \mathrm{g} / \mathrm{Kg}$. In the following the concentration measurement units are always reported as $\mu \mathrm{g} / \mathrm{Kg}$ and referred to dry weight.

\subsection{Statistical tools and methods.}

The software utilised for sample data processing was the $R(V .2 .11)$ software. The Probability Density Functions (p.d.fs.) referred to each sample distribution were computed by means of the translation method of Johnson (1949). In order to fit frequency curves, we have largely utilised R package SuppDist (Wheeler - 2005. SuppDists: Supplementary distributions. R package version 1.0-13). This software gives the following outputs: the density function [dJohnson()], the distribution function [pJohnson()], its inverse [qJohnson()]. Finally, the summary function [sJohnson()] provides a list of the whole statistical parameters of the distributions. The calculation algorithms for the estimate of the Johnson parameters are those of Wheleer (1980: quantiles method), and Hill, Hill and Holder (1976, moments method). We refer to Giovanardi et al (2006), for more details about practical applications of the Johnson method to the case of several coastal waters quality parameters.

\section{Results}

The data discussed in the following are to be referred to the analytical results provided by IFREMER. These data are related to 122 sampling stations scattered along the coasts of the Western Mediterranean sea. They cover a whole monitoring period of 3 years (2004-2006). We try therefore to provide a detailed picture by analysing punctually different accumulation values and identifying sampling sites were higher are the contamination levels.

\subsection{PCBs}

A major contribution to the total PCB accumulation is given by two congeners, both hexachlorobiphenyls, PCB 153 and PCB 138; their accumulation levels found in mussels recovered, are mapped in Fig. 1 and Fig. 2.

The congeners PCB 31, 52, 156 and 180 have not been detected in a large amount of sampling sites. In any case, the most contaminated samples are the mussels recovered in areas directly impacted from major industrial and urban settlements and/or river discharges.

PCB 153 and 138 show maximum accumulation levels along the French coast, in particular at the Marseille basin (Huveaune river: $42.3 \mu \mathrm{g} / \mathrm{Kg}$ and $27.6 \mu \mathrm{g} / \mathrm{Kg}$, respectively, Cortiou river: $36.1 \mu \mathrm{g} / \mathrm{Kg}$ and $18.8 \mu \mathrm{g} / \mathrm{Kg}$ ) and close to the Rhone river mouth $(13.9$ and $9.2 \mu \mathrm{g} / \mathrm{Kg})$. 
The two congeners, in the same order, are found at significant levels along the Italian coasts (Napoli: $28.0 \mu \mathrm{g} / \mathrm{Kg}$ and $19.0 \mu \mathrm{g} / \mathrm{Kg}$, Bagnoli: $16.0 \mu \mathrm{g} / \mathrm{Kg}$ and 12.0 , Gaeta: $13.0 \mu \mathrm{g} / \mathrm{Kg}$ and 10.0 $\mu \mathrm{g} / \mathrm{Kg}$ ) and at the Barcelona area (Llobregat river: $18.1 \mu \mathrm{g} / \mathrm{Kg}$ and $14.4 \mu \mathrm{g} / \mathrm{Kg}$. Barcelona: 11.0 $\mu \mathrm{g} / \mathrm{Kg}$ and $8.2 \mu \mathrm{g} / \mathrm{Kg}$. Besos river: $10.5 \mu \mathrm{g} / \mathrm{Kg}$ and $7.6 \mu \mathrm{g} / \mathrm{Kg}$ ).

Among the coastal sites located in Sardinia, highest levels have been detected at La Maddalena (PCB 153: $26,0 \mu \mathrm{g} / \mathrm{Kg}$; PCB 138: $12,0 \mu \mathrm{g} / \mathrm{Kg}$ ), while among North Africa coastal sites, Algiers shows considerable values for PCB 153 and 138, $20.5 \mu \mathrm{g} / \mathrm{Kg}$ and $14.1 \mu \mathrm{g} / \mathrm{Kg}$ respectively. For the remaining Mediterranean sites, detected accumulation values for both congeners do not exceed 10 $\mu \mathrm{g} / \mathrm{Kg}$. It is however worthy of note the case of Tunisia coasts, where the congeners 153 and 138 are well recognised in all the monitored sites, with concentrations constantly around 4 and $6 \mu \mathrm{g} / \mathrm{Kg}$. The PCB congeners 101 and 118, both pentachlorobiphenyls, are only occasionally found along the $\mathrm{W}$ Mediterranean coasts in detectable concentrations. Along the Italian peninsula the values usually range from <D.L. to $18 \mu \mathrm{g} / \mathrm{Kg}$ for PCB 101 and from < D.L. to $12 \mu \mathrm{g} / \mathrm{Kg}$ for PCB 118 . The Gulf of Naples provides the highest accumulation values. Significant concentrations are also recorded from Livorno to Nice, including the Genova harbour, in particular at the Haven shipwreck site.

Mussels recovered along France coasts provide accumulation values ranging from <D.L. to 16.3 $\mu \mathrm{g} / \mathrm{Kg}$ for PCB 101 and from <D.L. to $8.4 \mu \mathrm{g} / \mathrm{Kg}$ for PCB 118. Maximum concentrations have been found at the metropolitan area of Marseille (Huveane river discharge), but well detectable concentrations can be also recorded in the remaining French sites. In Spain, PCB 101 ranges from $<$ D.L. to $14.8 \mu \mathrm{g} / \mathrm{Kg}$, PCB 118 from <D.L. to $7.2 \mu \mathrm{g} / \mathrm{Kg}$. Sampling sites of Ebro river, Barcelona, Besos and Llobregat rivers provide, for both the congeners, concentrations well above the D.L.

Along the Africa coasts, levels exceeding the D.L. have been only found at Algiers, whereas Tunisia sites show very low concentrations. Similar situation regards the coasts of the major islands, where the congeners 101 and 118 are always close to the detection limit; the mono ortho PCB 105 is detected at low levels in Livorno harbour, in the Haven shipwreck site, in Zinola, La Maddalena, and in general at the main metropolitan areas of Marseille, Naples, Barcelona, Algiers, etc. The trichlorobiphenyl PCB 28 has been found at detectable concentrations in many sites: in Italy values range from $<D$.L. to $6,50 \mu \mathrm{g} / \mathrm{Kg}$ with the maximum levels found in Montalto di Castro and Naples; in France from <D.L. to $7,7 \mu \mathrm{g} / \mathrm{Kg}$ (Marseille); in Spain PCB 28 was found ranging from $<$ D.L. to $7,2 \mu \mathrm{g} / \mathrm{Kg}$ in the Columbretes islands, whereas in the North of Africa this congener was almost always undetectable.

\subsection{Pesticides}

Among pesticides taken into consideration by the "Mytilos Project", the isomers $\alpha \mathrm{HCH}$ and $\gamma \mathrm{HCH}$ were always under the D.L., in all the sampling stations. Concerning pp'-DDT and its metabolites, the greatest contribution to the total (as Derived DDT substances - DD's), is given by pp'-DDE, whereas pp'-DDT and pp'-DDD were in general only occasionally found in detectable concentrations. However, the accumulation levels for each DDT metabolite in the mussels are depicted and mapped in Figs. 3, 4 \& 5.

As already described for PCB levels, in terms of total DD's accumulation, the most contaminated samples were recovered at the Marseille coastal area, with $16.6 \mu \mathrm{g} / \mathrm{Kg}$ at the Huveaune river, 9.9 $\mu \mathrm{g} / \mathrm{Kg}$ at the Rhone river mouth and $6.1 \mu \mathrm{g} / \mathrm{Kg}$ at the Cortiou river. In the remaining part of the French coast, from Marseille up to Barcelona, the levels of DD's accumulation in the mussels oscillates around $10 \mu \mathrm{g} / \mathrm{Kg}$.

In the Barcelona metropolitan area, Llobregat river site shows values similar to those found at the Huveaune river, with $16.2 \mu \mathrm{g} / \mathrm{Kg}$ as DD's, and $10.6 \mu \mathrm{g} / \mathrm{Kg}$ at Besos river, while the remaining Spanish sites provide DD's values ranging from $12.1 \mu \mathrm{g} / \mathrm{Kg}$ (Ebro river) to $6.5 \mu \mathrm{g} / \mathrm{Kg}$ (Cap de Creus). Peak DD's values comparable with the Marseille situation are also found in the Gulf of Naples, with $15.3 \mu \mathrm{g} / \mathrm{Kg}$ at the metropolitan area of Naples and $11.2 \mu \mathrm{g} / \mathrm{Kg}$ at the Sarno river discharge. Less than $10 \mu \mathrm{g} / \mathrm{Kg}$ are instead found in the remainder of the Italian peninsula, with 8.1 $\mu \mathrm{g} / \mathrm{Kg}$ at Gaeta, $6.9 \mu \mathrm{g} / \mathrm{Kg}$ at the Tiber river mouth, $5.7 \mu \mathrm{g} / \mathrm{Kg}$ at Forte dei Marmi, $5.3 \mu \mathrm{g} / \mathrm{Kg}$ at Bagnoli and $5.2 \mu \mathrm{g} / \mathrm{Kg}$ at la Maddalena. Concerning the African coast, significant DD's 
accumulation levels have been found in Algiers (two sampling sites with $10.9 \mu \mathrm{g} / \mathrm{Kg}$ and 6.1 $\mu \mathrm{g} / \mathrm{Kg}$ ).

As far as single metabolites accumulation values, pp'-DDE concurs to the total DD's amount in the mussels with a contribution that, on average, exceeds $80 \%$, but well detectable concentrations of pp'-DDT are always found in the same locations where total DD's are high, as along the French coast at the Marseille basin, with $4.2 \mu \mathrm{g} / \mathrm{Kg}$ (Huveaune river) and $1.9 \mu \mathrm{g} / \mathrm{Kg}$ (Rhone river mouth). In Spain, pp'-DDT levels above the D.L. are found near Ebro river $(2.5 \mu \mathrm{g} / \mathrm{Kg})$, Llobregat river $(2.4$ $\mu \mathrm{g} / \mathrm{Kg})$ and at some sampling sites along the Southern coast, as e.g. Fuengirola $(1.4 \mu \mathrm{g} / \mathrm{Kg})$, Marbella $(3.1 \mu \mathrm{g} / \mathrm{Kg})$ and Algeciras $(1.2 \mu \mathrm{g} / \mathrm{Kg})$. In Italy the highest DDT concentrations have been observed in the Gulf of Naples, with $6.0 \mu \mathrm{g} / \mathrm{Kg}$ (Naples urban area), $1.6 \mu \mathrm{g} / \mathrm{Kg}$ (Bagnoli industrial area) and $1.4 \mu \mathrm{g} / \mathrm{Kg}$ (Sarno river discharge). Other sites showing DDT values just above D.L. are located along the Liguria coast (Zinola) and in Sardinia $(1.3 \mu \mathrm{g} / \mathrm{Kg}$ found at La Maddalena and at Cagliari).

The African coast is not free from pp'-DDT contamination. Several sampling sites, mainly along Moroccan and Algerian coasts, show in fact accumulation levels well above the D.L. with $3.7 \mu \mathrm{g} / \mathrm{Kg}$ at Nador, $1.7 \mu \mathrm{g} / \mathrm{Kg}$ at Melilla, $1.6 \mu \mathrm{g} / \mathrm{Kg}$ at Cap de Trois Fourches, $2 \mu \mathrm{g} / \mathrm{Kg}$ at Oran and Algiers, while Tunisia provides only one site with pp'-DDT detectable concentrations, Sidi Daoud, with 1.1 $\mu \mathrm{g} / \mathrm{Kg}$.

\subsection{Statistical elaborations}

After considering changes in accumulation contaminant values and identifying critical areas along the W Mediterranean coastal development, we have taken into consideration the frequency distributions of the data as a whole, in order to study the statistical behaviour of single DD's and PCB species.

Johnson's transformations applied to the original data, allow to compute a wide variety of nonnormal distributions, including distributions which are bounded on either one or both sides. Each of the raw DD and PCB frequency class distributions have been approximated to an appropriate type of probability distribution and classified depending on the related moments, in a general scheme of reference, as shown in Fig. 4

The reference system for distribution types is build up in the $\left(\beta_{1,} \beta_{2}\right)$ moments plan, with $\beta_{1}=$ skewness to the square and $\beta_{2}=$ kurtosis +3 . Log-normal system is defined by the points lying on the $S_{L}$ line. The curves with a variation range bounded at both the extremities pertain to the System Bounded $\left(S_{B}\right)$. This system covers the region between the log-normal line and the straight line where it is worth the relationship: $\beta_{2}-\beta_{1}-1=0$. Beyond this line the impossible area extents, where the combinations requested between $\beta_{1}$ and $\beta_{2}$ for distributions identifying, will never happen. Finally the system of curves unbounded at either extremity (System Unbounded: $S_{U}$ ), covers the remaining part of the $\left(\beta_{l,}, \beta_{2}\right)$ plan, below the $\mathrm{S}_{\mathrm{L}}$ line.

An inspection of the diagrams in Fig. 4, shows that the prevailing type of frequency distribution for several DD and PCB species belongs to the Bounded Family, that is to say that the theoretical variation range is of a finite kind. On the contrary, resulting distributions for pp'-DDT, pp'-DDE, PCB 153 and PCB 28 are strictly of (or very close to) Log-Normal type, without limits on the right side.

The graphical representation of the frequency curves, shown in Fig. 5, allows "to certify" the contamination level in the Western Mediterranean basin, in terms of probability density functions and associated concentration range of variation, for each of the DD and PCB species taken into consideration.

The shape and the type of these curves may represent therefore a further element of judgement and surely need appropriate attention in future monitoring campaigns and researches, in order to characterize different areas and try to better understand how the mechanisms of the accumulation work. 


\section{Discussion}

\subsection{Interpretation of the Mytilos Project results}

As it is well known, the class of substances object of the present work, due to their hydrophobic behaviour, enters the marine environment mostly in absorption on particles suspended along the water column. Sediments work therefore as a trap for PCBs and pesticides and represent a natural matrix to be considered in order to assess chemical contamination (WHO, 1993; Erickson, 1997; Tolosa et al. 1997).

The use of mussel caging technique can really provide additional information on the contamination levels, in terms of bio-accumulation, that is to say in terms of amount of chemical contaminant absorbed by (and probably interacting with) a living organism.

To give account of the results obtained, it is necessary to recall the procedures and strategies pursued in the Mytilos Project. Cages were usually located where the effect of human activities was presumably elevated: at the important metropolitan areas with the related harbours, at large industrial settlements, at the mouth of major rivers, with the related polluting loads, and so on. Alternatively, several sites, chosen as reference sampling stations (blank), were also selected at non-impacted areas. The purpose was clear: to characterize critical areas by identifying the accumulation levels of specific contaminants and, in the same time, to assess background values for all the detected substances and to report the gap between non-polluted and polluted areas. This is in fact the key to be adopted in analysing and interpreting the overall results.

\subsubsection{PCBs}

Referring to PCBs accumulation results, we observe that congeners PCB 153 and 138 assume the role of predominant contaminants. In practice, the contribution of these congeners is so prevailing that their variations in the different sampling sites determine the overall changes as total PCBs. We have to remark that many authors report data about the preferential accumulation of PCB 153 and 138 in marine organisms tissues (Boon and Eijgenraam, 1988; Colombo et al., 1995, 1997; Kamman et al, 1992; Bayarri et al., 2001; Thompson et al., 1999; Turrio Baldassarri et al., 1993). Investigations carried out on mussel bio-accumulation mechanisms show that PCBs with a higher molecular chlorine content are accumulated in a larger extent than those with a lower chlorine content (Geyer H. et al., 1982, 1984; Thompson et al., 1999). Degradation of PCBs in the environment largely depends on the degree of chlorination and, in general, their persistence increases with the degree of chlorination. Micro-organisms are able to degrade mono-, di- and trichlorobiphenyls rapidly and tetrachlorobiphenyls slowly, whilst higher chlorinated biphenyls are quite resistant to biodegradation (WHO, 1993).

Nevertheless, we have also to remark that PCB 180 and 156, that are hepta and hexachlorobyphenyls respectively, in our investigations resulted mostly under the D.L.

Although the degree of bioaccumulation has been closely related with the number of chlorine atoms and hydrophobicity (represented by the octanol-water partition coefficient (Kow)), congeners with high Kow values have reduced bioavailability for mussels, due to their high affinity for the sediments (Edgar et al., 2006). This high affinity for the sediments may explain that PCB 180 and 156 specific behaviour.

Moreover, taking into consideration the employ of products based on PCBs for various economic and productive sectors, we observe that commercial mixtures of PCBs available on the markets are a mix of congeners and differ from each others depending on their percent composition. Each country has its own trademark of industrial mixture, Clophen in Germany, Fenchlor in Italy, Phenochlor in France and so on, and the percent content of PCB congeners is quite varied. It seems therefore reasonable to conclude that actual contamination levels of PCBs, as shown by the Mytilos Project, are the result of multiple factors affecting the fate of PCB congeners entering the coastal environment:

the prevailing percent composition of the PCB commercial mixtures employed,

the effective occurrence along the coasts of relevant point sources, that determine high accumulation levels as total PCBs (critical areas),

the different degree of persistence for each congener, depending on the number of chlorine substitutions on the biphenyl rings. 
the physico-chemical properties of the PCB congeners (Kow, vapour pressure).

A final comment concerns the occurrence of low chlorinated PCB in marine organisms. The accumulation in a mussel sample of congeners like e.g. РCB 28 , should thus be interpreted as evidence of recent pollution. On the other hands, due to their low molecular weight, the contamination pathways of low chlorinated PCBs is preferably aerial deposition, that is to say that it should be problematic to ascribe their occurrence in marine environment to some identifiable local land based source.

\subsubsection{Pesticides}

DDT, as organochlorine insecticide, has been used in large amounts since 1940 to combat the larvae and adult stages of insects (including mosquitoes). Starting from 1972, its utilisation has been severely restricted in almost all the European countries, but it is worth to remark that nowadays there are still significant concentration values for this molecule in the marine environment.

About the environmental fate of pesticides such as p,p'-DDT, literature provides a lot of references. A meaningful and illuminating overview is reported on a technical document of the Agency for Toxic Substances and Disease Registry (ATSDR - U.S. Department of Health and Human Services - Sep. 2002), to which we refer for any further and detailed deepening $\left({ }^{1}\right)$. It was observed that the loss of the active ingredient of the pesticide from the tilled layer of the soil was to be ascribed to complex phenomena of volatilization, leaching and microbial degradation. Four fundamental processes were identified: Transport, Phases partitioning, Transformation and Degradation. DDT and its metabolites are transported from one medium to another by solubilisation, adsorption, remobilization, bioaccumulation and volatilization. In addition, they can be transported within a medium by currents, wind and diffusion. As far as degradation, it was reported that chemical transformation of the original DDT molecule may occur by abiotic and biotic processes. Several studies show that bio-degradation may occur under both aerobic and anaerobic conditions, due to soil micro-organisms, including bacteria, fungi, and algae. Since DDT initially biodegrades to DDD or DDE, there still may be dangerous compounds remaining after almost all of the DDT that was originally present has biodegraded. DDE, the dominant DDT metabolite found, is often resistant to further biodegradation. In laboratory experiments with marine sediments, DDT has been shown to degrade to DDE and DDD under aerobic and anaerobic conditions, respectively. It was finally reported that DDT breaks down into DDE and DDD in soil, and the parent-to-metabolite ratio (DDT to DDE or to DDD), although varying considerably depending on the soil type, decreases with the time.

This preamble was needed for a correct interpretation of the overall Mytilos Project results. It must be therefore clear now that what we have measured as DD's accumulation in the mussels represents the final result of all the processes mentioned above.

Firstly we have to highlight the similarity of the PCBs and DD's spatial distribution: higher accumulation values are found at the main metropolitan areas and at the mouth of important rivers. There is however evidence that river inputs represent the most important source of pesticides entering the Western Mediterranean sea: DDs could mainly be river transported and, therefore, accumulated in river mouths by flocculation/sedimentation of suspended particulate matter (Tolosa et al., 1995). The Ebro river basin can be taken as an example. This basin represents the most economically important area of the North Iberian Peninsula. The primary sources of organochlorine compounds are industrial and agricultural activities along the basin (Fernandez et al., 1999). Gómez-Gutiérrez et al. (2006) report data on the annual loading for DDs, on the basis of the results of a monthly sampling campaign, from November 2002 to October 2003: a total of 50 $\mathrm{kg} /$ year of DDs were evaluated as discharged by the Ebro river, being the pp' DDT the major constituent $(33 \mathrm{~kg})$ followed by pp' DDD $(9 \mathrm{~kg})$ and pp' DDE $(8 \mathrm{~kg}) .66 \%$ of the total DD's was mainly associated with suspended matter.

$\left({ }^{1}\right)$ "Toxicological profile for DDT, DDE, and DDD". In particular, we refer to Chapter 6 "Potential for human exposure". All the topics discussed and the studies cited in the following, are accompanied by an extensive bibliography. 
Along the French coasts, in addition to Rhone and Marseille areas, relatively high levels of DD's accumulation in the mussels are found along the coastal lagoons, e.g. at Agde and Têt sampling stations (see also Villeneuve et al., 1999). This can be interpreted as a consequence of large use of pesticides in the past for mosquitoes control. DDT was widely used in fact in agriculture (e.g. rice cultivation in Camargue - Berny et al, 2001).

As far as the Italian situation, DD's contamination levels are quite modest. Highest levels of DD's accumulation have been found at the Gulf of Naples (mainly because of the Sarno river basin contributions. Sarno river is a relatively small water course, characterised by a large catchment area, ca. $500 \mathrm{~km}^{2}$, where intensive farming together with livestock breeding and related tanning industries, are prevailing economic activities).

About the contribution of the various metabolites, usually p,p'-DDE prevails on the total DD's composition. The DDT contribution becomes relevant only in some coastal locations, such as Barcelona area, Rhone basin and Gulf of Naples. In the light of the above discussion, the occurrence of p,p'-DDT as such in the mussels, could be interpreted as evidence of recent contamination or, better said, as a proof of the employ of DDT in the related tributary basins, despite the existing regulations. Frankly speaking, after more than three decades from which the ban was initiated, it is difficult to support the thesis of a direct contamination under way for our mussels, due to the spreading of DDT on crops. It is instead likely to consider other indirect contamination routes, e.g. re-mobilisation from surrounding sediments or from runoff of fluvial sediments DDT-ladened, entering the coastal system.

In the Southern part of the W Mediterranean sea, significant accumulation values of DDT in the coastal environment are recorded at the Nador Lagoon (Morocco) and along Algerian coast. The absolute DDT concentration values are comparable with those related to the most polluted areas of the Northern part of the basin. In relative terms, the percentage of p,p'-DDT on the total DD's amount recorded, exceeds $40 \%$ at Oran sampling station and $70 \%$ at Nador. These percentages so elevated can surely be interpreted as a more recent form of contamination. In the particular case of Nador, we have to point out that the intensive farming activities developed in the area give rise to high loads of chemicals and fertilizers, affecting directly coastal environment ( Cheggour et al, 2002; Sabhi Y. et al., 1999).

\subsection{Preliminary classification of DD and PCB accumulation levels.}

The study of the frequency distributions of each DD's and PCB species allows to adopt a probabilistic approach to the accumulation levels, for classification purposes.

Once a particular Johnson curve has been fitted, the normal integral can be used to compute the expected percentage points under the respective curve. In other words, from the p.d.f., specific for each contaminant as shown in Fig. 5, we can evaluate a) the probability of exceeding a given concentration value or, viceversa, b) the concentration value corresponding to a probability level, fixed a priori. These results are obtained by means of the command JohnsonFit() of the R Program and the related functions pJohnson and qJohnson respectively.

The following Table summarises theoretical variation ranges for each DDT metabolite and PCB congener.

Tab. 1 Western Mediterranean sea: reference system for pesticides (DD's) and PCB's accumulation in Mytilus galloprovincialis.

Lower and upper boundary values, corresponding to significant percentiles of the area under the curve of the related p.d.f.

\begin{tabular}{lcccccccccc}
\hline & $\begin{array}{c}\text { Sample } \\
\text { size (*) }\end{array}$ & $\mathbf{0 . 0 1}$ & $\mathbf{0 . 0 5}$ & $\mathbf{0 . 1}$ & $\mathbf{0 . 2}$ & $\begin{array}{c}\mathbf{0 . 5} \\
\text { (media } \\
\text { n value) }\end{array}$ & $\mathbf{0 . 8}$ & $\mathbf{0 . 9}$ & $\mathbf{0 . 9 5}$ & $\mathbf{0 . 9 9}$ \\
Condition Index & 122 & 0.056 & 0.059 & 0.063 & 0.070 & $\mathbf{0 . 0 9 9}$ & 0.144 & 0.166 & 0.180 & 0.195 \\
Lipids (\% content) & 122 & 1.5 & 2.7 & 3.3 & 4.1 & $\mathbf{5 . 7}$ & 7.9 & 9.5 & 11.1 & 14.9 \\
\hline
\end{tabular}




\begin{tabular}{lrllllllllc}
\hline DD's $(\mu \mathrm{g} / \mathrm{Kg} \mathrm{D.W.})$ & 99 & 0.9 & 0.9 & 1.0 & 1.2 & $\mathbf{2 . 3}$ & 5.8 & 8.5 & 10.5 & 13.0 \\
p p' DDE & 98 & 0.9 & 1.0 & 1.1 & 1.3 & $\mathbf{1 . 9}$ & 3.5 & 5.1 & 7.1 & 13.5 \\
p p' DDT & 26 & 0.9 & 1.0 & 1.1 & 1.2 & $\mathbf{1 . 6}$ & 2.5 & 3.2 & 4.0 & 6.5 \\
p p' DDD & 32 & 1.0 & 1.0 & 1.0 & 1.1 & $\mathbf{1 . 5}$ & 2.7 & 3.8 & 4.8 & 6.2 \\
Total PCBs $(\mu \mathrm{g} / \mathrm{Kg}$ D.W.) & 122 & 1.1 & 1.3 & 1.5 & 2.1 & $\mathbf{5 . 1}$ & 15.2 & 27.0 & 42.0 & 83.8 \\
PCB 28 & 61 & 0.5 & 1.1 & 1.3 & 1.5 & $\mathbf{2 . 0}$ & 3.0 & 4.4 & 6.4 & 15.0 \\
PCB 101 & 32 & 0.7 & 0.9 & 1.1 & 1.5 & $\mathbf{3 . 6}$ & 8.8 & 12.2 & 14.6 & 17.5 \\
PCB 105 & 16 & 1.0 & 1.0 & 1.0 & 1.1 & $\mathbf{1 . 4}$ & 2.2 & 2.9 & 3.7 & 5.5 \\
PCB 118 & 33 & 1.0 & 1.0 & 1.1 & 1.2 & $\mathbf{1 . 8}$ & 3.8 & 5.7 & 7.7 & 11.4 \\
PCB 138 & 80 & 1.0 & 1.1 & 1.2 & 1.4 & $\mathbf{2 . 6}$ & 6.2 & 9.9 & 14.1 & 23.1 \\
PCB 153 & 95 & 0.8 & 1.0 & 1.2 & 1.5 & $\mathbf{3 . 0}$ & 7.3 & 12.2 & 18.8 & 42.9 \\
\hline
\end{tabular}

(*) Note: in analysing data, only concentration values $\geq$ analytical detection limit were taken into account (i.e. $\geq 1$ $\mu \mathrm{g} / \mathrm{Kg}$ D.W., both for DDs and PCBs).

In the above table, two important physiological parameters have been also considered; Lipids (\% content in the mussel tissues) and Condition Index (C.I., i.e. the ratio between the dry weight of the mussel tissues and the weight of the shells - Andral et al. 2004 ). The analysis of the data by means of the linear regression analysis, does not prove the hypothesis of a possible effect on the accumulation values, by these parameters: considering single data points, very low or null significance of the correlation coefficients was always found, that is to say that DDs and PCBs accumulation levels do not seem to be affected by some physiological status parameter. However, while ungrouped value statistics result in lower or null correlation, the group statistics may provide some significant level of correlation. This is the case of the regression DDs vs $\log (\mathrm{C} . \mathrm{I}$.), as reported in Fig. 6, where average values (medians) of DDs, referred to nine geographically homogeneous groups of sampling stations, are plotted against the respective C.I. log-values.

The calculation procedures adopted for these contaminant compounds, allow therefore to compute the accumulation values corresponding to each percentage point of the related probability distributions. Two general cumulative curves, representing a diagrammatic version of the Reference System already presented in the above table, have been draught (Fig. 7). Single experimental observations can be now judged by comparison in terms of low or high accumulation, with regard to their location relative to the lowest or to the highest values, within the full value range identified by the cumulative probability curves. For this purpose, the median DD and Total PCB accumulation values, referred to each of the regional coastal reaches already identified above, were ranked along the respective curves, in such a way that an immediate and visual representation of the overall results of the "Mytilos Project" has been provided. Due to the strong non-normality conditions of the sample original distributions, instead of the Group Means and Standard Deviations, the more robust parameters: Medians and Median Absolute Deviations (MAD) have been taken into consideration $\left(^{2}\right)$.

Referring to a standard 12 weeks period of exposure, we can now propose a preliminary classification criterion for the accumulation rates in the Western Mediterranean basin, by considering three classes:
a) DD's (as $\mu g / K g ~ D . W$.
b) Total PCBs (as $\mu \mathrm{g} / \mathrm{Kg} \mathrm{D.W}$.)
Low $<1.5 \leq$ Medium $<3.7 \leq$ High
Low $<3.1 \leq$ Medium $<8.8 \leq$ High.

The chosen concentrations are those defined respectively by the Thirty-third and Sixty-sixth percentile of the comprehensive DD's and PCBs distributions, as already shown in the Fig 7

The proposed criterion reflects the actual variation range of the experimental data and, at least for the moment, it excludes any implication of eco-toxicological nature. It does not provides further elements of judgement with reference to the degree of hazard and possible harmful consequences on the surrounding biological communities, or risk for human health.

At this concern, we can refer to the classification system proposed by the European Environmental Agency (EEA - 2006). Three classes of low, moderate and high contamination levels in Mytilus sp.,

$\left({ }^{2}\right)$ Examining the diagrams in Fig. 4, it seems that Tunisia (for PCBs) and Morocco-Algeria (for DD's) result more impacted than France or Italy. It is worth mentioning that the medians are not affected by maximum values, being these graphical representations indicative of "average" conditions as such, and without taking into account local and/or critical situations. 
were set up for PCBs (as sum of 7 congeners) and DD's (as sum of p,p'-DDE and p,p'-DDD). The lower and upper concentration ranges for moderate class, are: 0.001-0.01 mg/kg, for DD's and: 0.003-0.03 $\mathrm{mg} / \mathrm{kg}$, for PCBs. These boundaries were defined taking in account both ecotoxicological assessment criteria (EAC) and background/reference concentrations (BRC), as suggested by OSPAR (1999). The upper limit was taken as 10 times the lower. Unfortunately these boundaries are reported as referred to Wet Weight. Data obtained from the Mytilos Project give an average water content in the mussel samples around $80 \%$, in such a way that, by adjusting the measurement units, we can adapt the EEA criterion as follows:
a) DD's (as $\mu \mathrm{g} / \mathrm{Kg} \mathrm{D.W}$.)
Low $<5 \leq$ Moderate $<50 \leq$ High
b) Total PCBs (as $\mu \mathrm{g} / \mathrm{Kg} \mathrm{D.W.)}$
Low $<15 \leq$ Moderate $<150 \leq$ High.

Clearly, the two classification criteria are not comparable. By following EEA criterion, all the sampling sites of the Mytilos Project would pertain to the low class, except for some local situation belonging instead to the moderate class, without never exceeding the lower limit of the high class.

\section{Conclusions}

A question arises concerning the environmental meaning and the implications of the overall Mytilos Project results: what is the consistency of our data with the real contamination levels of the Western Mediterranean sea? Are these data truly representative of critical situations and to what extent? Trying to give an answer to these questions, we have analysed analogous results on PCBs and DD's accumulation in biota, derived by similar monitoring campaigns on natural mussel populations.

Respect for example PCBs, the occurrence in biota of these organochlorinated compounds along the Iberian coasts has been investigated, since 1991, by Spanish research institutes (Campillo et al., 2004; Deudero et al., 2007), by means of a monitoring network of several sampling stations, using mussels belonging to natural populations as bioindicators. Highest PCB accumulation were identified in mussels sampled at Barcelona metropolitan area and Ebro river mouth (428 and 120 $\mu \mathrm{g} / \mathrm{kg}$ D.W. respectively, as sum of 7 congeners, in May-June 2004). Lower concentrations ranging from 61 to $71 \mu \mathrm{g} / \mathrm{kg}$ D.W. were found more southward, at other industrial cities, like Valencia, Malaga and Cartagena and Balearic Islands. These data appear to be in contrast with those provided by the present study. Our accumulation values result much lower, ranging in the Barcelona area from 30 to $60 \mu \mathrm{g} / \mathrm{kg}$ D.W., at Ebro river around $20 \mu \mathrm{g} / \mathrm{kg} \mathrm{D.W.,} \mathrm{as} \mathrm{total} \mathrm{PCBs.} \mathrm{The}$ other coastal sites show values around $5 \mu \mathrm{g} / \mathrm{kg}$ D.W. We should conclude therefore that, under natural conditions, Mytilus galloprovincialis populations accumulate much more, although a basic information like the exposure time is virtually unavailable.

In the above paragraphs we have often talked about "accumulation levels" of contaminants in the caged mussels. Actually, we should instead talk about "accumulation rates", having to refer the measured concentrations to the length of the exposure time, i.e. to a constant period of 12 weeks. For this reason, it is not so scientifically correct to test the likeness of our results with the data provided by the existing literature on biota contamination.

And on the other hand, analysing the Mytilos Project data, we have not found strict evidence of functional interrelationships between some mussel physiological parameters, like Condition Index and $\%$ content of lipids, and amount of accumulated contaminant, and also we do not know exactly what could happen halving or doubling the exposure time of the cages. Clearly the use of single data obtained by means of the caging technique is limitative, in the sense that it does not provides information about the dynamic of contamination. The broad array of the dynamic processes (caseby-case accumulation curves in the time for each determinant, effects of different physiological parameters on the rates of accumulation, changes in accumulation rates due to physical parameters characterising any coastal area, and so on), will have to be added by appropriate research, both in the field and in laboratory. But ultimately, these issues are of secondary importance, if the main objective is instead to put in operation a surveillance network at a regional scale by standardizing procedures and strategies. The "active mussel watch" approach, developed and applied in the Mytilos Project is general, not geographically bound. On the other hand, 
statistical analysis of the data, as demonstrated in the previous paragraphs, has proved a great tool in order to understand the behaviour of different contaminants.

We conclude with a citation: "regarding the raving pollution from xenobiotic compounds, science and practice still struggle to attain not only the necessary knowledge, compound by compound, but to realize a corresponding conceptual framework to be able to decidedly establish what kind, and how much of xenobiotic loads are permissible in any given situation, to avoid serious long term damages to aquatic ecosystems" (Giovanardi and Vollenweider, 2004). If the caging technique really provides a standard measure of the contamination levels, we believe that our work could give an important contribution to the necessary basis of knowledge, requested for testing and improving eco-toxicological assessment criteria and to achieve this conceptual framework .

\section{Acknowledgments}

The authors wish to thank E. Amato and A.M. Cicero for supporting this project; C. Blottiere, E. Calabretta, C. Codina, V. Perini, F. Oteri, R. Piermarini, P. Boissery, H. Thebault, C. Tomasino , M. Elbour, A. Benrha, A. Moukrim, S. Messaoud, M. de Torres, M. Manzanera, S. Boukortte, A. Romana, E. Emery, F. Lagarde, C. Ravel and G. Hervé for their important contribution to the various project activities.

This research was supported by EEC ( Interreg /MedoccIIIC). Morocco Algeria and Tunisia were supported by UNEP MEDPOL

\section{References}

Agency for Toxic Substances and Disease Registry (ATSDR), 2002. Toxicological profile for DDT, DDE, DDD. Atlanta, GA: U.S. Department of Health and Human Services, Public Health Service.

Ahlborg, U.G., Becking, G.C., Birnbaum, L.S., Brower A., Derks, H.J.G.M., Feeley, M., 1994. Toxic equivalency factors for dioxin-like PCBs. Chemosphere 28, 1049-1067.

Amico, V., Chillemi, R., Impellizzeri, G., Oriente, G., Piattelli, M., Sciuto, S., Trincali, C., 1982. Levels of chlorinated hydrocarbons in sediments from the central Mediterranean., Sci. of the Tot. Environ., 24, 91-99.

Andral, B., Stanisiere, JY., Sauzade, D., Damier, E., Thebault, H., Galgani, F., Boissery, P., 2004. Monitoring chemical contamination levels in the Mediterranean based on the use of mussel caging, Marine Pollut. Bull. 49, 704-712.

Bayarri, S., Baldassarri, L.T., lacovella, N., Ferrara, F., Domenico, A.D., 2001. PCDDs, PCDFs, PCBs and DDE in edible marine species from the Adriatic Sea. Chemosphere 43, 601-610.

Bazzanti, M., Chiavarini, S., Cremisini, C., Soldati, P., 1997. Distribution of PCB congeners in aquatic ecosystems: a case study, Environ. Intern. 23, 799-813.

Berny, P., Sadoul, N., Dol, S., Videman, B., Kayser, Y., Hafner, H., 2001. Impact of local agricultural and industrial practices on organic contamination of little egret (Egretta garzetta) eggs in the Rhone Delta, Southern France. Environ. Toxicol. Chem. 21, 520-526.

Boon, J.P., Eijgenraam, F., 1988. The possible role of metabolism in determining patterns of PCB congeners in species from the Dutch Wadden Sea. Mar. Environ. Res. 24, 3-8.

Campillo, J., Franco, M., Martinez, F., Benedico J., 2004. Comparison of organic contaminant levels in mussels Mytilus galloprovincialis from the Mediterranean coast of Spain collected in 1993 and 2001. Rapp. Comm. Int. Mer Médit. 37, 177. 
Canesi, L., Scarpato, A., Betti, M., Ciacci, C., Pruzzo, C., Gallo, G., 2002. Bacterial killing by Mytilus hemocyte monolayers as a model for investigating the signaling pathways involved in mussel immune defence. Mar. Environ. Res. 54, 547-551.

Canesi, L., Betti, M., Ciacci, C., Scarpato, A., Citterio, B., Pruzzo, C., Gallo, G., 2002. Signaling pathways involved in the physiological response of mussel hemocytes to bacterial challenge: the role of stress-activated p38 MAP kinases. Developmental and Comparative Immunology 26, 325334.

Carvalho, F.P., Civili, F.S., 2001. Monitoring of the Mediterranean sea pollution (MED POL) and data quality assurance. Intern. J. Environ. Studies, 38, 139-158.

Cheggour, M., Chafik, A., Benbrahim, S., 2002. Biomonitoring the Morrocan coasts: outlook of the Mediterranean Mussel Watch in Morocco Mediterranean Mussel Watch - Designing a regional program for detecting radionuclides and trace-contaminants. CIESM Workshop Series [CIESM Workshop Ser.], 15, pp. 39-47.

Colombo, J.C., Bilos, C., Campanaro, M, Presa, M.J., Catoggio, J.A., 1995. Bioaccumulation of polychlorinated biphenyls and chlorinated pesticides by the Asiatic Clam Corbicula fluminea: its use as a sentinel organism in the Rio de la Plata, Argentina. Environ. Sci. Technol. 29, 914-927.

Colombo, J.C., Brochu, C., Bilos, C., Bandoni, P., Moore, S., 1997. Long-term accumulation of individual PCB, dioxins, furans and trace metals in Asiatic clams from Rio de la Plata Estuary, Argentina. Environ. Sci. Technol. 31, 3551-3557.

De Simone, R., 1994. Elementi in tracce e microinquinanti organici nei sedimenti marini costieri (da Gaeta a Punta Campanella). Acqua Aria 7, 623-628.

Deudero, S., Box, A., March, D., Valencia, J., Grau, A., Tintoré, J., Caixach, J., 2007. Organic compounds temporal trends at some invertebrate species from the Balearics, Western Mediterranean. Chemosphere 68,1650-1659

Edgar, P.J., Hursthouse, A.S., Matthews, J.E., Davies, I.M., Hillier, S., 2006. Sediment influence on congener-specific PCB bioaccumulation by Mytilus edulis: a case study from an intertidal hot spot, Clyde Estuary, UK. Journal of Environmental Monitoring 8, 887-896.

EEA - Indicator Fact Sheet - (WHS6) Hazardous substances in marine organisms DRAFT 04072006. Authors: N. W. Green, B. Bjerkeng (Norwegian Institute for Water Research).

Elder, D.L., Villeneuve, J.P., 1977. Polychlorinated Biphenyls in the Mediterranean sea. Mar. Pollut. Bull. 8, 19-22.

Environmental Health Criteria Series. Polychlorinated biphenyls and terphenyls (second edition). World Health Organization, Geneva, 1993.

Erickson Mithchell, D., 1997. Analytical Chemistry of PCBs, $2^{\text {nd }}$ ed. Lewis publishers, USA.

Fernàndez, M.A., Alonso, C., Gonzàlez M.J., Hernàndez, L.M., 1999. Occurrence of organochlorine insecticides, PCBs and PCB congeners in waters and sediments of the Ebro river (Spain). Chemosphere, 38, 33-43.

Geyer H, Sheenan P., Kotzias D., Freitag D., Korte F., 1982. Prediction of ecotoxicological behaviour of chemicals: relationship between physico-chemical properties and bioaccumulation of organic chemicals in the mussel Mytilus edulis. Chemosphere 11, 1121-1134. 
Geyer, H., Freitag, D., Korte, F., 1984. Polychlorinated Biphenyls (PCBs) in the marine environment, particularly in the Mediterranean. Ecotoxicol. Environ. Safety 8, 129-151.

Giovanardi, F., Vollenweider, R.A., 2004. Trophic conditions of marine coastal waters: experience in applying the Trophic Index TRIX to two areas of the Adriatic and Tyrrhenian seas. Journal of Limnology 63, 199-218.

Giovanardi, F., Finoia, M. G., Russo, S., Amori, M. and B. Di Lorenzo, 2006. Coastal waters monitoring data: frequency distributions of the principal water quality variables. J. Limnol. $65,65-$ 82.

Goldberg, E.D., 1975. The Mussel Watch. Mar. Pollut. Bull. 6, 111-113.

Gòmez-Gutiérrez, A.I., Jover, E., Bodineau, L, Albaigés, J., Bayona, J.M., 2006. Organic contaminant loads into the Western Mediterranean sea: estimate of Ebro river inputs. Chemosphere 65, 224-236.

Gunther, A., Davis, J., Hardin, D., Gold, J., Bell, D., Crick, J., Scelfo, G., Sericano, J., Stephenson, M., 1999. Long term bioaccumulation monitoring with transplanted bivalves in the San Francisco estuary. Mar. Poll. Bull. 38, 170-181.

Hill, I.D., Hill, R., and Holder, R.L., 1976. Fitting Johnson curves by moments. Applied Statistics. AS99.

Johnson, N.L., 1949. Systems of frequency curves generated by methods of translation. Biometrika 36: 149-176.

Kamman, U., Landgraff, O., Steinhart, H., 1992. Cyclic organochlorines in benthic organisms from the North Sea and the German Bight. Analusis Magazine 20, 70-73.

Kannan, K, Tanabe, S., Tatsukawa, R., 1995. Geographical distribution and accumulation features of organochlorine residues in fish in tropical Asia and Oceania. Environ. Sci. Technol. 29, 26732683.

Kock, W., Kramer, J.M., 1994. Active biomonitoring (ABM) by translocation of bivalve mollusks. In: K.J.M. Kramer, Editor, Biomonitoring of Coastal Waters and Estuarines, CRC Press, Florida, 5184.

Marchand, M., Vas, D., Duursma, E., 1974. Résidus de DDT et de polychlorobiphényles (PCB) dans les moules, le sediment et le plankton de la côte nord-ouest méditerranéenne. In: II $^{\text {es }}$ Journées d' Etudes Pollutions, C.I.E.S.M., Monaco, 171-174.

Ospar, 1999. Report on assessment of trends in the concentrations of certain metals, PAHs and other organic compounds in the tissues of various fish species and blue mussels: Ospar ad hoc Working Group on Monitoring 1998. 44 pp + appendices.

Puccetti, G., Leoni, V., 1980. PCB and HCB in the sediments and waters of the Tiber estuary. Mar. Pollut. Bull. 11, 22-25.

R Development Core Team, 2005. R: A language and environment for statistical computing. R Foundation for Statistical Computing, Vienna, Austria. ISBN 3-900051-07-0, URL http://www.Rproject.org.

Andral, B. and Stanisière, J.V., 1999. RINBIO - Réseau Intégrateurs Biologiques. Evaluation de la qualité des eaux base sur l'utilisation de stations artificielles de moules en Mèditerranée: résultats de la campagne 1998. Rapport détailleé, Agence de l'Eau Rhône Méditerranée Corse. 
Romeo, M., Hoarau, P., Garello, G., Gnassia-Barelli, M., Girard, JP., 2003. Mussel transplantation and biomarkers as useful tools for assessing water quality in the NW Mediterranean. Environ. Pollut. 122, 369-378.

Sabhi, Y., Chaoui, M., El Quessar, S., Bakkas, S., Ramdani, M, 1999-2000. Identification of the northern Moroccon hot spots and contamination baseline of coastal sediments by heavy metals. Bulletin de l'Institut Scientifique, Rabat, 22, 59-69.

Storelli, M.M., Storelli, A., D'Addabbo, R., Barone, G., Marcotrigiano, G.O., 2004. Polycholrinated biphenyl residues in deep sea fish from Mediterranean sea. Environ. Internat. 30, 343-349.

Thompson, S., Budzinski, H., Garrigues, P., Narbonne, J.F., 1999. Comparison of PCB and DDT distribution between water-column and sediment-dwelling bivalves in Arcachon Bay, France. Mar. Pollut. Bull. 38, 655-662.

Tolosa, I., Bayona, J.M., Albaiges, J., 1995. Spatial temporal distribution, fluxes, and budgets of organochlorinated compounds in northwest Mediterranean sediments. Environ. Sci. Technol. 19, 2519-2527.

Tolosa, I., Raedman, J.W., Fowler, S.W., Villeneuve, J.P., Dachs, J., Bayona, J.M., Albaiges, J., 1997. PCBs in the western Mediterranean. Temporal trends and mass balance assessment. Deep Sea Res. II 44, 907-928.

Turrio Baldassarri, L., di Domenico, A., Fulgenti, A.R., lacovella, N., La Rocca, C., 1993. Differences in polychlorobiphenyl (PCB) contamination pattern in various environmental matrices, The Sci. of the Total Environment, Supplement, 1439-1451.

UNEP/FAO, 1990. Assessment of the state of pollution of the Mediterranean sea by organohalogen compounds. MAP Technical Reports Series No.39. UNEP, Athens, 224 pp.

UNEP/WHO, 1999. Identification of Priority Pollution Hot Spots and Sensitive Areas in the Mediterranean. MAP Technical Reports Series No.124. UNEP, Athens, 110 pp.

Villeneuve, JP., Carvalho, S., Fowler, SW., Cattini, S., 1999. Levels and trends of PCBs, chlorinated pesticides and petroleum hydrocarbons in mussels from the NW Mediterranean coast: comparison of concentrations in 1973/1974 and 1988/1989. The Sci. Tot. Environ. 237/238, 57-65.

Wheeler, R.E., 1980. Quantile estimators of Johnson curve parameters. Biometrika 67, 725-728.

WHO, 1993. Polychlorinated Biphenyls and Terphenyls (second edition). Environmental Health Criteria 140, International Programme and Chemical Safety, World Health Organizations (Geneva). 


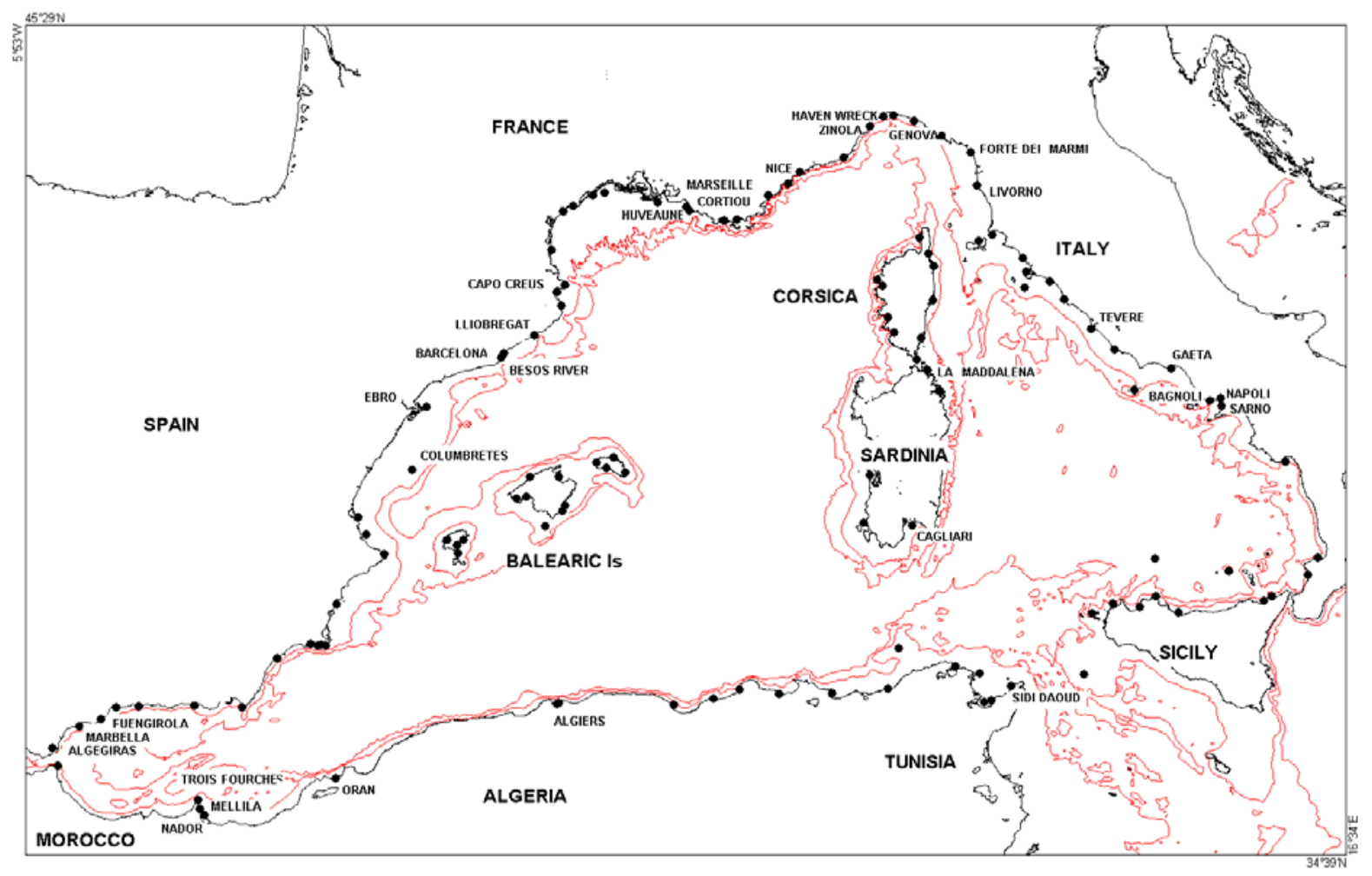

Fig. 1 Sampling stations of the MYTILOS project for active biomonitoring of the Western Mediterranean coasts. Each station consisted of $2-4$ cages of $3 \mathrm{~kg}$ of mussels maintained as described in materials and methods. 

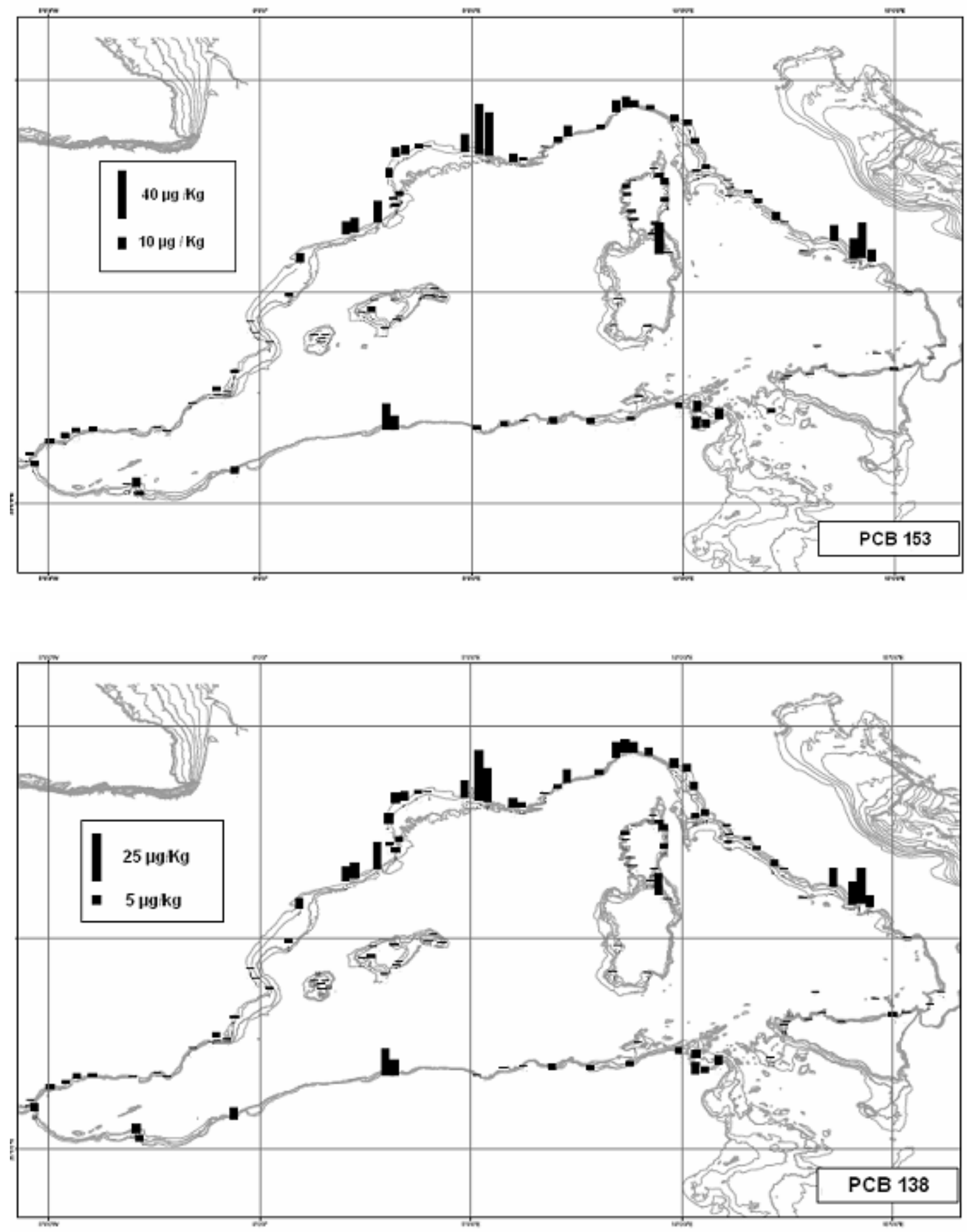

Fig. 2 Levels of PCB 153 and PCB 138 ( $\mu \mathrm{g} / \mathrm{Kg}$ Dry weight) in mussels caged along the coast of the Western Mediterranean basin. 

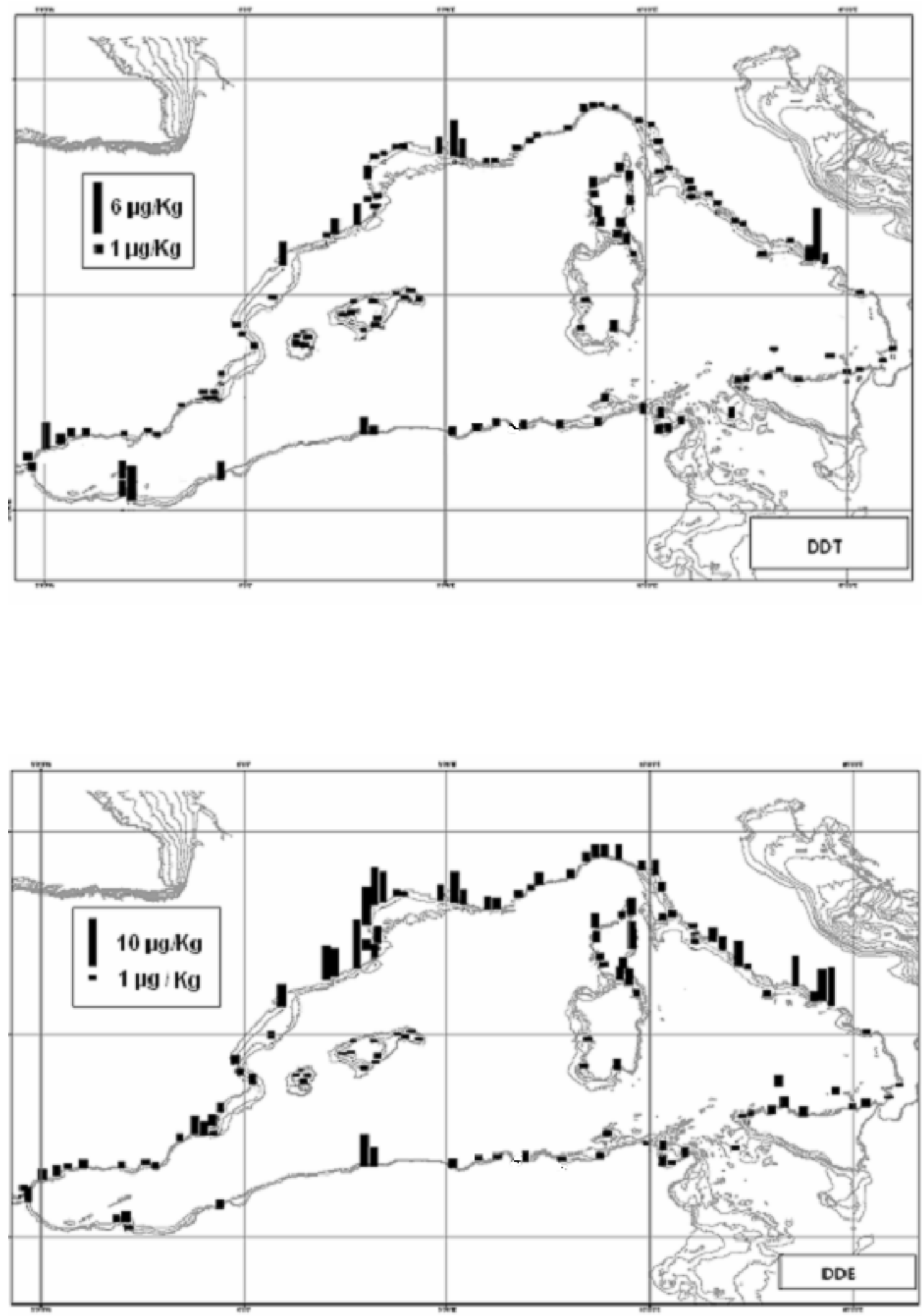


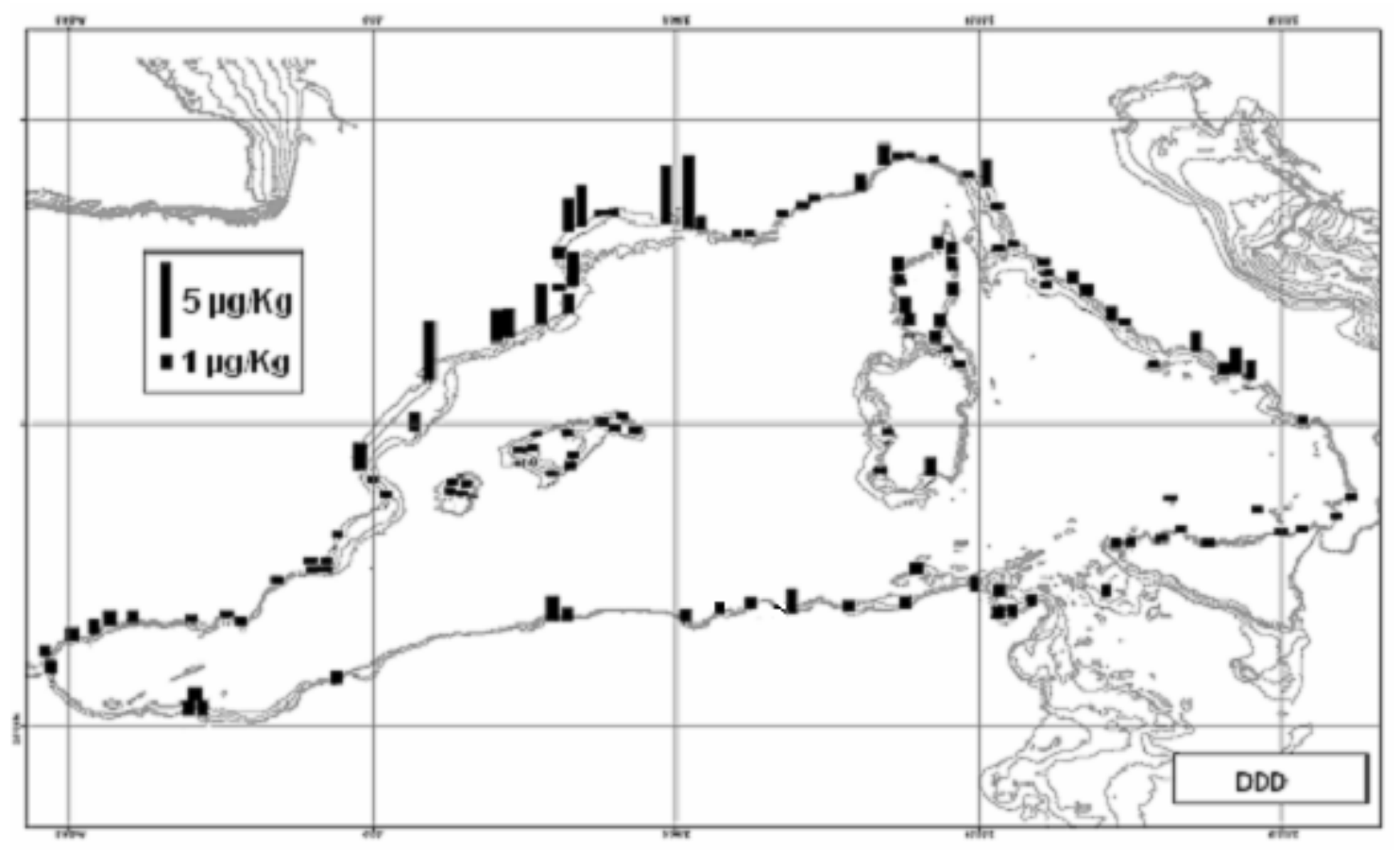

Fig. 3 Levels of DDT, DDD and DDE ( $\mu \mathrm{g} / \mathrm{Kg}$ Dry weight) in mussels caged along the coast of the Western Mediterranean basin. 

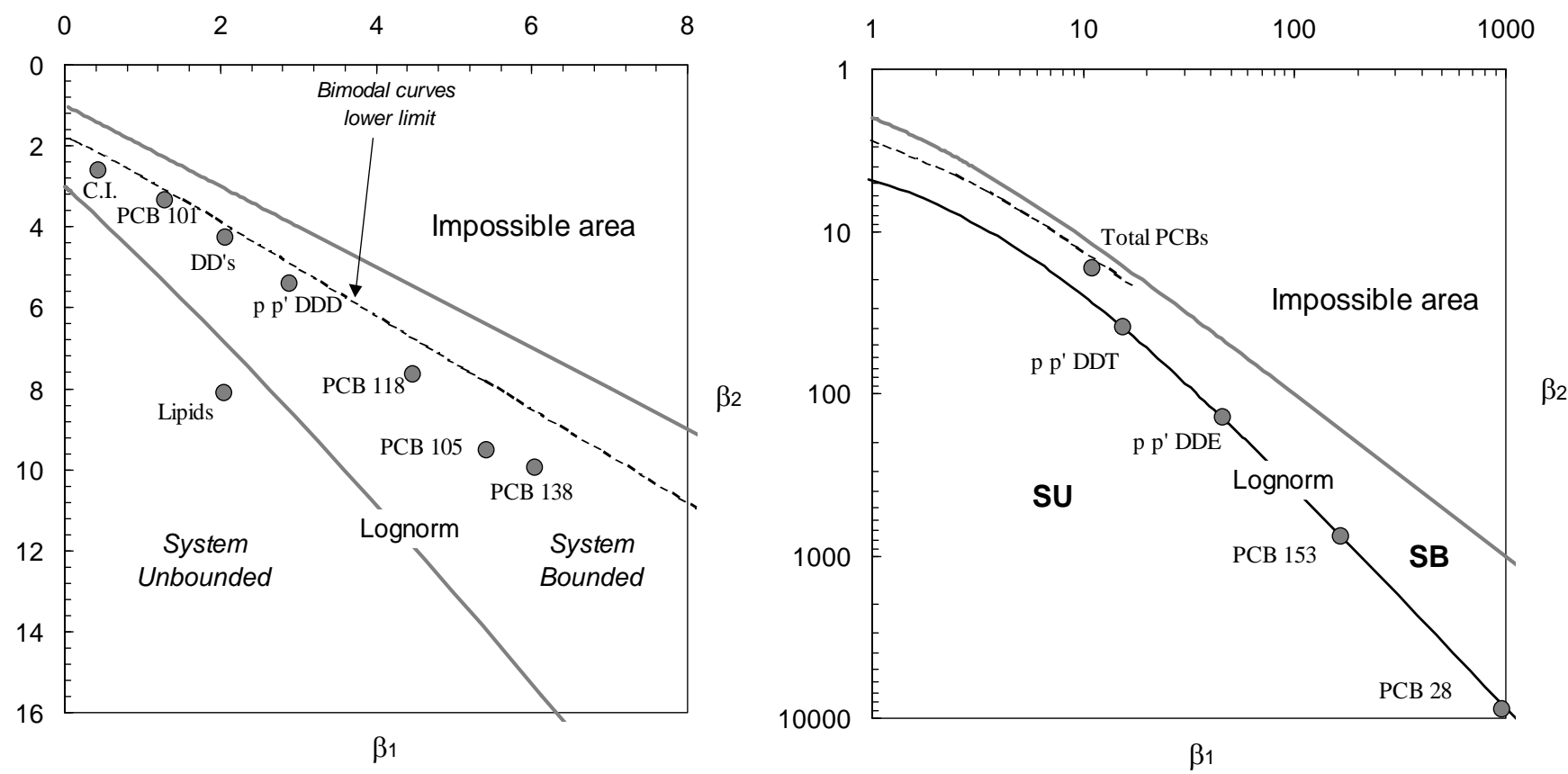

Fig. 4 Western Mediterranean sea: DD and PCB species accumulation in Mytilus galloprovincialis. The Johnson scheme of frequency curves classification, depending on moments $\beta_{1}$ and $\beta_{2}$. 
DD's

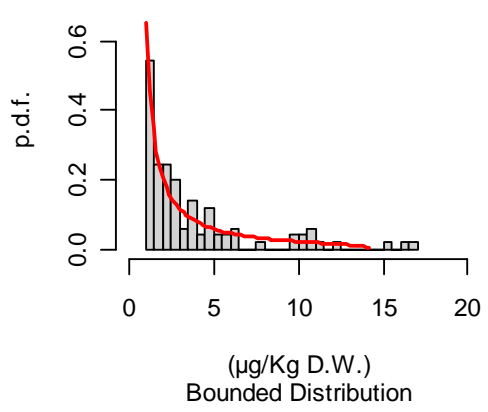

pp'DDT

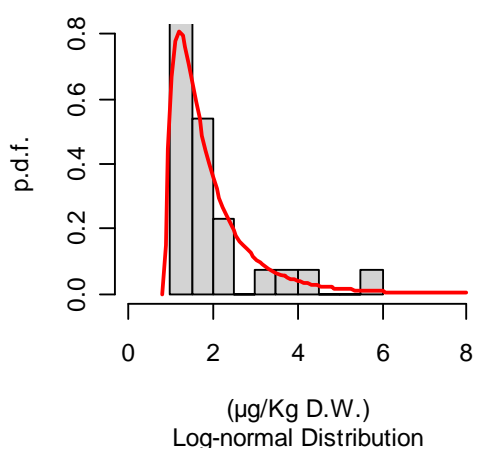

Total PCBs

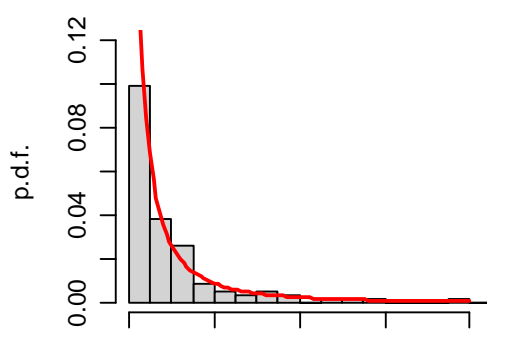

$\begin{array}{lllll}0 & 20 & 40 & 60 & 80\end{array}$

( $\mu \mathrm{g} / \mathrm{Kg} \mathrm{D.W.)}$

Bounded Distribution

PCB 138

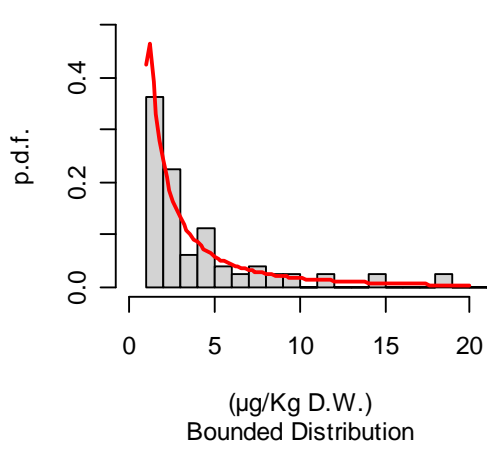

pp'DDE

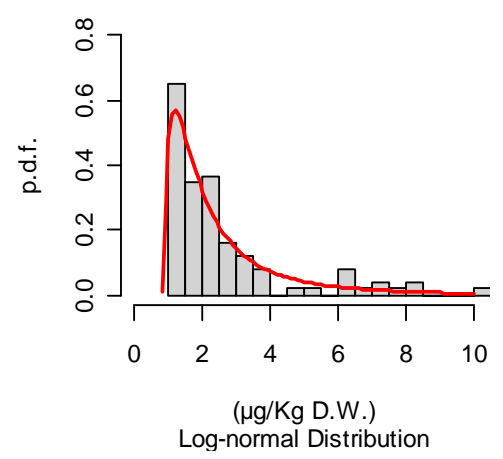

pp'DDD

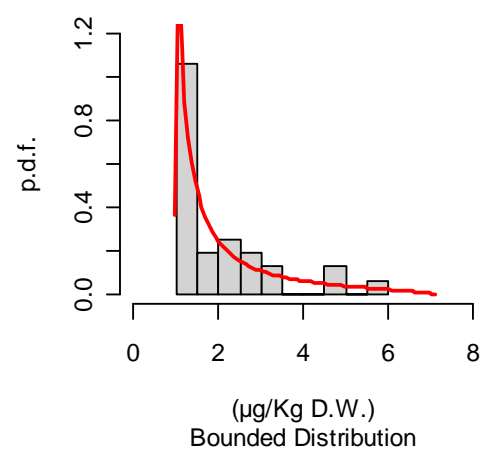

PCB 28

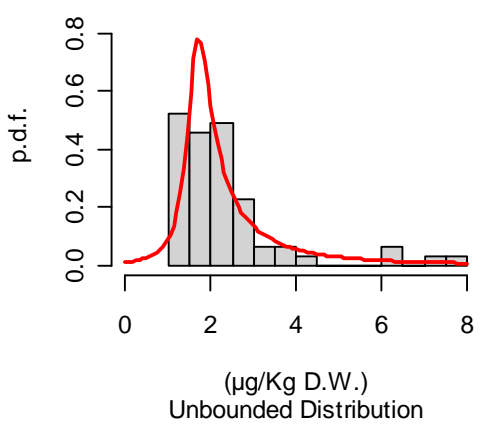

PCB 153

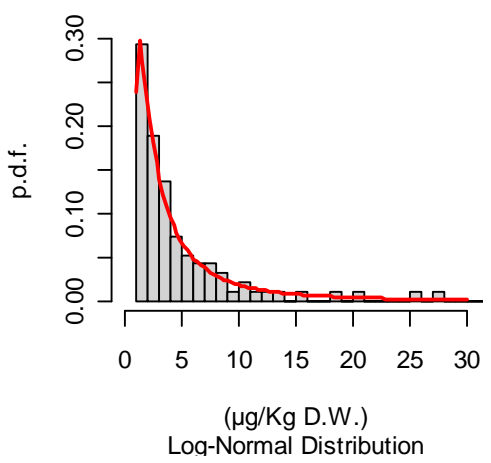

Fig 5

Fig. 5 Accumulation levels in M. galloprovincialis, for some DD and PCB congeners in Western Mediterranean basin. Frequency distributions and related Probability Density Functions. 


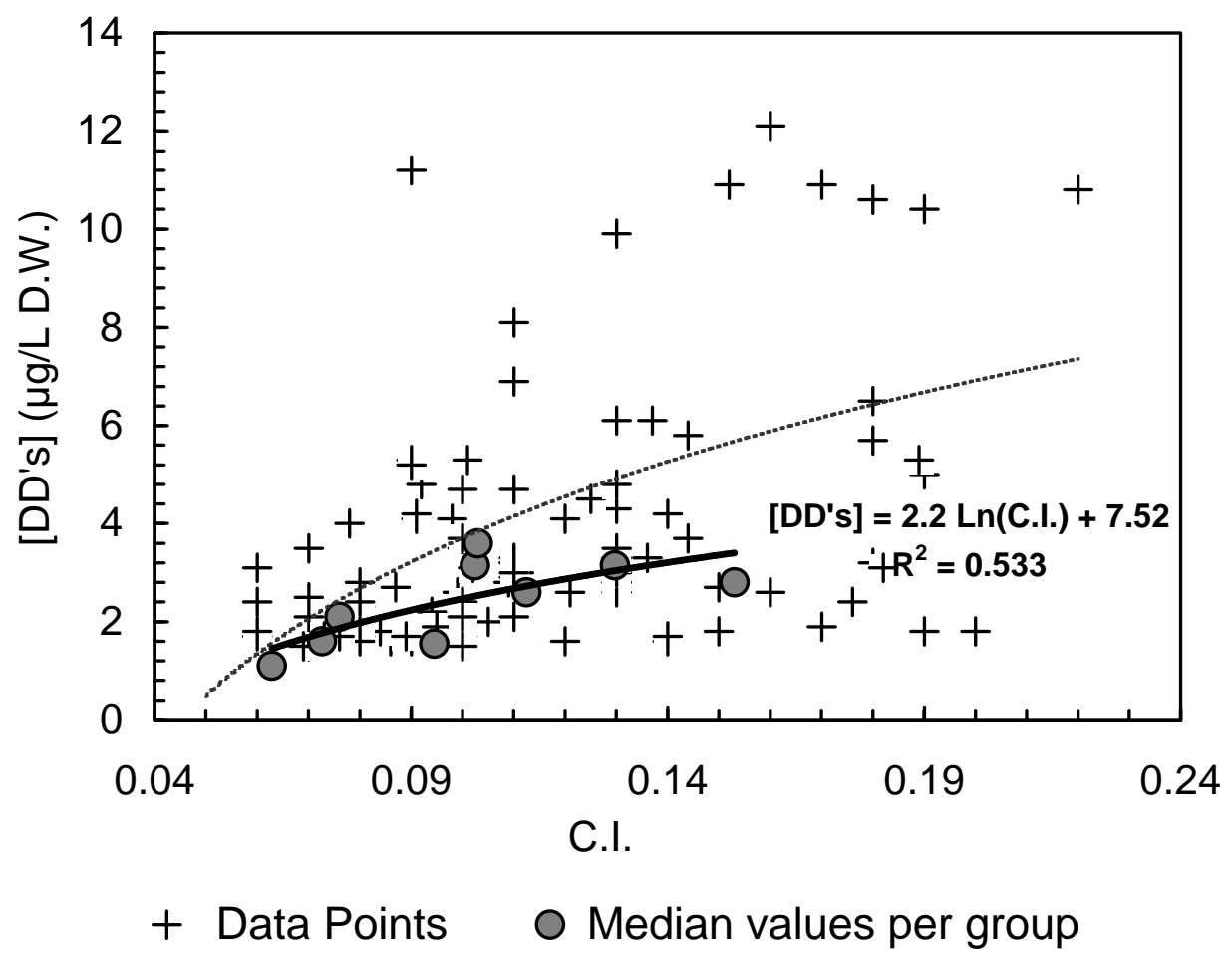

Fig. 6 Western Mediterranean sea: regression between DD accumulation values in the mussel tissues and the related Condition Index (log-values). 


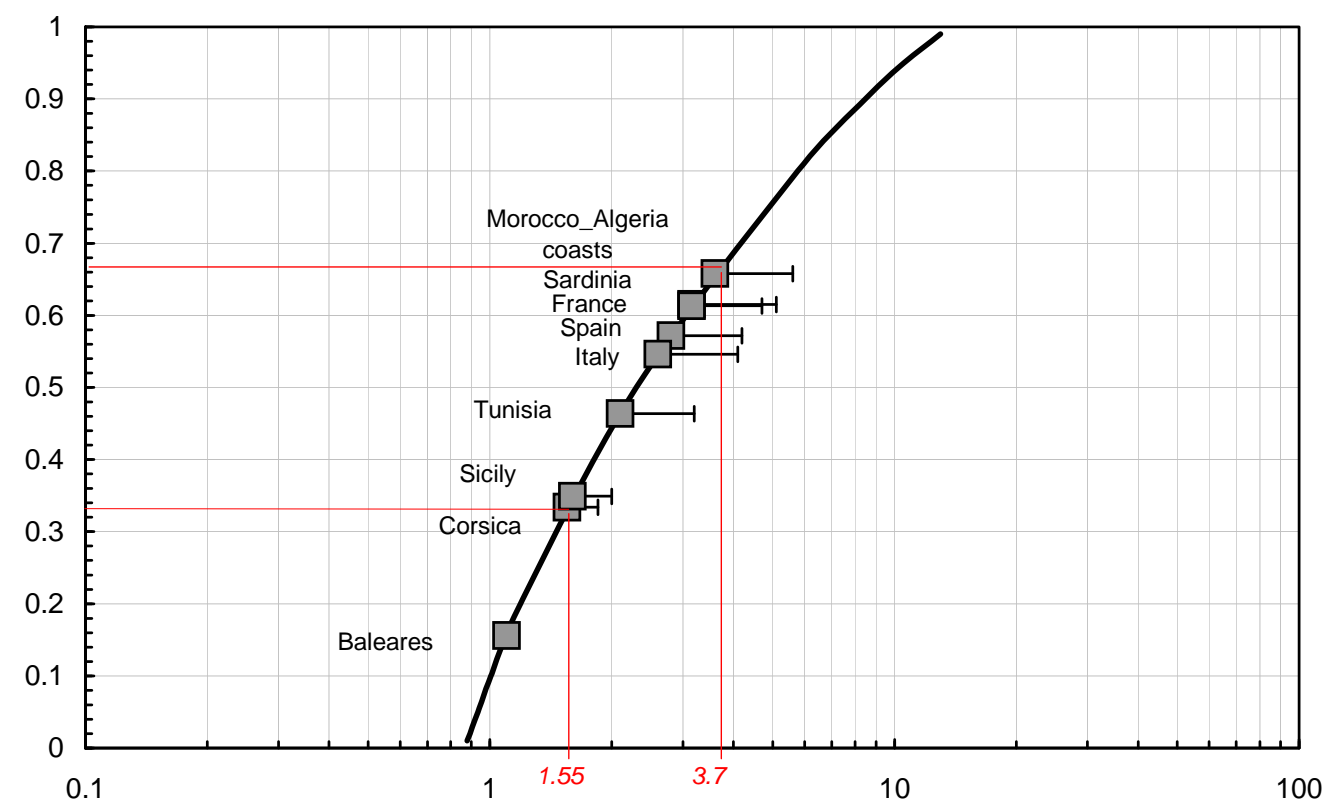

A $\quad[\mathrm{DD}$ 's] $\mu \mathrm{g} / \mathrm{kg}$ D.W.

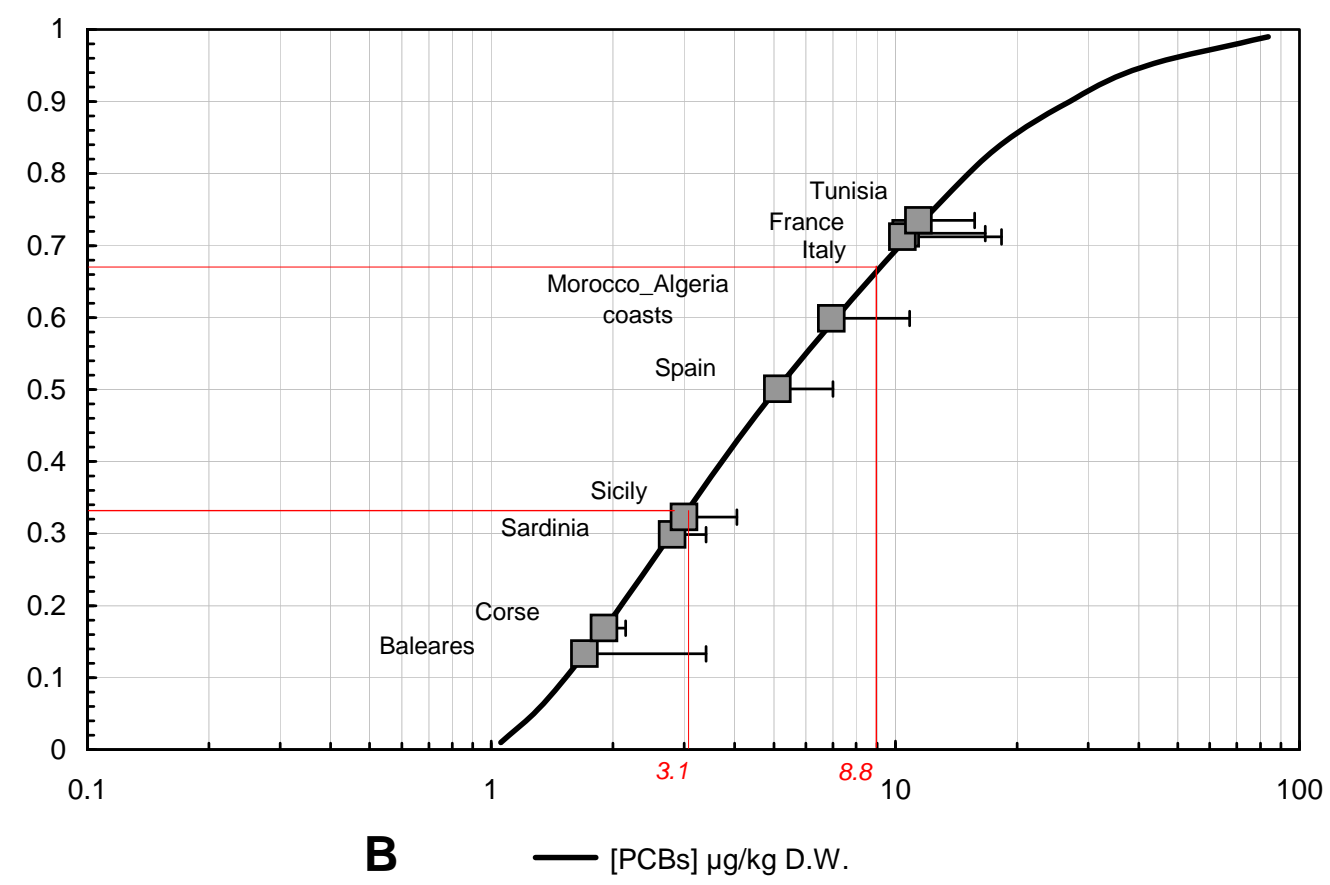

Fig. 7 Western Mediterranean sea: Pesticides (A) and Total PCBs (B) accumulation in Mytilus galloprovincialis. Cumulative probability distribution functions and relative location of the median values per geographical areas.

(Note: error bars $=+M D A$ ). 